\title{
Governance of Public Funding Research Technologies: Technology Welfare Governance Model
}

\author{
Vithal Kumar Lakkineni ${ }^{1}$, Archana Tiwari ${ }^{2}$ \\ ${ }^{1}$ Center for Research Studies, Noida International University, Noida, UP, India \\ ${ }^{2}$ School of Sciences, Noida International University, Noida, UP, India
}

\begin{abstract}
This paper analyzes rationality of the government funding in public research and its levels of public benefit. This is basically theoretical and vision paper for practical utility. In diffusing research output to the public there is a very thin line of difference between benefit and profit. Public funding institutions try their level best to release their technology to the public and private companies also fulfill the needs through commercialization, but the intentions of making much bigger profits damaging motive of public benefit, sometimes leading to failure in technology absorption or aversion. In this scenario public funded research institutes and government are facing much criticism. To minimize the discrepancy between, technology innovation and absorption this paper discusses about the combination of Innovation management in public research institutes and Technology welfare governance model in dispensing technology.
\end{abstract}

Keywords: Public funding, research Institutes, Agriculture, Technology, welfare, governance

\section{Introduction}

The technology developments for past few decades made everything globalized and research lab to market became common phenomena. The time for creating new innovations reduced considerably and there is an urgency to reach out people with the innovations in the same intensity. So the responsibility of public research institutes and government doubled in channelizing technology benefits to the people and market. In reaching people through market anything can be patented and anything can be marketed attitude of public research institutions may do more harm than good. The benefit motive of public research tilted more towards market than public. Many of the public research institutes and governments still lagging behind in utilizing the benefits of the public funding research outputs because lack of coordination policy which is suitable for public and market. The policies regarding market sharing, protection of intellectual property rights, public private partnership are well evolved nationally and internationally. The markets grown so fast in globalization because of participation policy of the governments to take benefit of it. The same participation policy is required in science and technology in innovation absorption. There is need of new policies which can absorb and channelize technology outputs directly to the people. Now to spread the research benefits in health, agriculture and food sectors the governments have to create technology oriented policies.

The spending of the governments in all the research funding is mostly from taxes from the people or funded by the international funding agencies to support public welfare motive of the government. Some funding from the international organizations is on credit based which means the credit should be paid back by the government through public taxes. But the success of public research organizations will be successful only when the research benefits reach back to the people. For the purpose of giving technology benefits to the people regulation of technology transfer by the public research instituteis important.

Today we are seeing completely market polarized world in Pharmaceutical research and production of drugs. The government is trying their level best trying to keep prices low. Many of the lifesaving drugs are so costly that the poor can't afford. But in an agrarian country like India, where government funding is more in research there is much need to do regarding implementation of technology innovations. The research in transgenic and other agriculture developments is needed to focus on future food scarcity problems. The concept paper may work for all public funding research organizations, but mainly focused with view on Agriculture research organizations.

In research intangible assets play a major role. The creation of innovations and multiplying the benefits of these innovations by a strong policy mechanism and advancement of these innovations for the public benefit is also important for welfare governance. In addition to the demographic dividends, the recent government initiatives of startup companies, Make in India programs are also will bring new innovative technologies. There are lots of mediums like voluntary involvement of corporations in social responsibility, self help groups, and farmers associations to work towards Technology welfare governance through an established policy by the government engaging Public funding research organizations. The public funding research institutions should develop a mechanism on diffusion of innovations through government welfare policies, this will help a welfare government can play more active role in, adaptation, and absorption and expansion activities. 


\section{International Journal of Science and Research (IJSR) \\ ISSN (Online): 2319-7064}

Index Copernicus Value (2015): 78.96 Impact Factor (2015): 6.391

\section{Material and Methods}

This study had been done in a holistic view of governance, market and public benefit output in research institutes. This gives a theoretical note and compact idea by the author highlighting the need of reinventing public policy on technology welfare governance. Finally the study would suggest Innovation management model for public research institutes and successful transfer of technology innovations to the government.

\section{Results and Discussion}

\subsection{International National Scenario Results}

Today it is a fact that expenditure in public research labs became so high. In many developing countries the cost of world class research facilities, instrumentation and backup needs are imported from developed countries. We have to realize that the funding to do research is not in another way to do business. Instead of choosing unwanted goals or facing unwarranted situations with those research outputs the research funding and government policy should focus and local agriculture needs on first priority. Instead of forcing or polarizing the developing countries innovation policy to dump all the public money on research related expenditure, the developed countries should help them in 'technology recreation, modification and adoption' first.

At present India is the front runner in space technology in developing low cost satellites. This happened because of hard work, dedication, implementation skill of point zero risk precautions and precision of a plan which have all the chances of failure. The coordinated efforts of space scientists and the government policy made it possible. The intellectuals, technology, knowledge resources are so vast in our country and having the capability of feed the entire world if we have a coordinated technology welfare governance policy which can work on lab to farm low cost technologies and implementation.

The aura of India, as green revolution country is eclipsing with farmer suicides. Tomorrow we may become the first country to find a living place on other planet but we should not consider ourselves as a successful country till the time every single human on our planet is getting enough food and place to live. The inspiration of this space technology success should spill the same dedication and efforts in the agrarian sector technology outputs also.

The International regional groups like SAARC, ASEAN BRICS which have agrarian resources and common agrarian problems should have a 'Common Technology InnovationImplementation Cooperation Policy (SAARC-CTIICP)' on agriculture innovations, technology transfer and benefit sharing. Western countries should show big hearts in sharing the technology transfer to developing countries realizing that, humanity only can benefit each other in this regard. Developing countries may need to take lead policy experimentation and Innovation. It is applicable to a developing country like India. Policy makers may have to confidently suggest data to design the balance of public and private interests in an emerging transnational system of innovation ${ }^{[1]}$

Development of new technologies and implementation should be so fast with and simultaneous technology trails, transparent reports, success assessment and re-modification is needed If these technologies are in the hands of few private people or few developed countries to get profits or to show their authority then definitely we may have to shift to another planet to save our lives.

\subsection{Role of research outputs in welfare governance}

When a technology impacts a large number of people in a larger area in a methodological way in a fixed time, penetrating the technology at different levels of public strata, considering the domestic factors, depending on the advantage it will change the lives to better living, that can be taken as a parameter of benefit and for a successful technology. The research and scientific developments today leading us to create new techno innovations in all the areas particularly in health and agriculture (Ex. Vaccines, transgenics and new farm machineries) to developing needs and more productivity. The focus of public funding research should be to fallow benefits then market approach. Government policy should mention the parameters for measuring public benefits with technology outputs by research organizations.

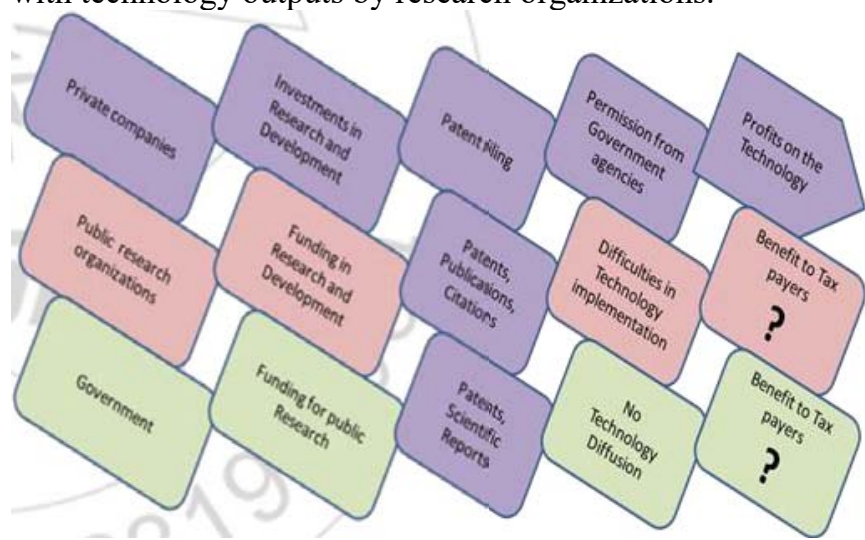

Figure 1: Technology flow from research labs to market. This indicates comparison of output flows in private companies, public research organizations and the government. The output of private research always to get profit. The research outputs in public funded research institutes go through the process of technology transfer, industry collaborations and license to private companies.

Government need to balance public benefit and market demand. Research institutions in the developed countries have enough funds to do research and catch the developments. The project budget, technology output, returns on profits, research publications are not real parameters to do public good. Invention and adoption are real parameters of public research.

In developed countries the public research and private research go hand in hand in producing goods and many people are able to buy the services. Here the market systems, farm mechanisms, research funding mechanisms; technology transfer mechanisms are well established. They can expand 


\section{International Journal of Science and Research (IJSR) \\ ISSN (Online): 2319-7064 \\ Index Copernicus Value (2015): 78.96 | Impact Factor (2015): 6.391}

their business or can explore market easily where the resources are available. Middle- and low-income countries differ widely in their research and technological competencies, governance of research systems, and more broadly, in their level of economic development and culture of innovation ${ }^{[2]}$

In case of research outputs by the public funding research institutes in developing countries, they are trying to reach this kind of market mechanisms and industry partnerships. The public private partnership can be acceptable when there is a strict guideline on benefit sharing with public (WIPO guidelines, 2012).

That market policy for the technology spread in R\&D sector may not work in agrarian dependent countries, low income level countries, politically unstable countries, policy nascent countries. The same market policy or collaborative research with industries delivery mechanisms may not benefit people in these countries and people will look at government for policies which will benefit them. This is the reason many governments give subsidies and loans to the people for welfare.

If public funding research organizations go on approaching market with technology innovations only those technologies which are profitable to companies will reach public domain [3]. Demand driven technologies only given preference. The technologies which may give large benefits but no profits, will not reach people due to lack of proper procedure. Here the question is not why public funding research organizations are approaching market but the question is who will monitor needs of the people, government or markets, 'Can we do benefit to the people with this market approach in public research institutes. Is it justifiable to think of market demand and profit before discussing how much benefit we give to the society with this technology. The technology diffusion programmes by the institutes through different mechanisms at different levels meet little success. The recent trends of technology transfer, pricing, valuation mechanisms of research institutions giving more value to market than the technology diffusion at ground level.

\subsection{Government should involve in Technology Welfare}

Technology diffusion capability of a country depends on the scientific advancement, knowledge, human capital, income levels, need, and technology absorption capacity of the people and capability of integrating innovations with policies. For this government has to overcome technical, environmental, economic and administrative challenges at implementation.

If the public research institutions and government together can't build up a strong mechanism to deliver benefits of these developments, then market will capture it for profits. If we analyze the recent controversies on transgenic agriculture crops, not going in to the debate of whether these crops are good or bad, definitely there is a problem in approaching the end users without any innovation preparedness or government policy involvement. Here it is important to quote the "National Consultations on Bt Brinjal report" which made many significant remarks regarding introduction of new technology and reminded the policy responsibility of different Ministries and Departments in the government.

"The GM crop issue does have great public policy significance and cannot be confined to the scientists alone. Scientists, like everyone else, know what they know and do not know what they do not know. They are not omniscient. Even when totally objective, whatever they say is based only upon the present state of their knowledge. Thus legislations must consider concerns of stakeholders that extend beyond science". (Proposition No.84 CEE, 2010: 72)

"Scientific invention alone is not the basis for large scale application of a technology. It is for society to draw up their limits based on ethics and plain good sense and whatever they come up with by remaining within those limits, decide what is acceptable and what must be rejected". (Proposition No.85 CEE, 2010:72) ${ }^{[4]}$.

This is one of the first, technological consultation report of its kind in democratic India, involving all stake holders like government, scientists, agriculture experts, farmers' organizations, consumer groups and NGOs. At the stage of new technology implementation market penetrated like anything without giving a chance to authenticate and launch the technology in more appropriate method by the government taking consideration of farming community, consumers and civil society. Scientific community is defending the technology but because of rejection from the end users government is facing legal and ethical uncertainty in granting permission.

Every innovation depending on it is complexity, requires a methodological approach in this regard. A proper plan on innovation preparedness will deal with educating the end users regarding new technology and programme implementation, Today many states are not willing to provide space even for BT field trails. Can we consider this as a failure of the government policy, public research institutes or private companies who tried to exploit the loopholes existed in an agrarian country? In many developing countries this happened because of lack of coordination between government institutions, technology assessment, monitoring, dependency on market mechanisms, transparency of regulatory authorities and lack of mechanism to address the concerns of the end users. If research institutions and the government has failed in their technology diffusion after spending corers in extension units and developing mechanisms, the market is going to fulfill this gap. The entry of transgenic might have succeeded by the private sector in an agrarian country with the help of government.

The innovator can't take his innovation to the ground level where it will work. We need an approach where everyone will involve as a chain of participation from innovator to the end users. In this process we want to integrate project preparations, innovations and adoption in accordance with welfare governance policy.

The technology transfer and diffusion $(T \& D)$ required more in environmental, agriculture and health sectors. It needs public participation, implementation through public Inter organizational linkages, delivery mechanisms of public reach, agriculture technologies can be linked to employment 


\section{International Journal of Science and Research (IJSR) \\ ISSN (Online): 2319-7064}

Index Copernicus Value (2015): 78.96 Impact Factor (2015): 6.391

creation programs. Government should show its presence to benefit people.

Any new innovations have its own advantages and disadvantages, but it is the responsibility of the government how they are dealing with it and with the public otherwise technology will be abandoned by the people before seeing the results. From fast few years we didn't see any revolutionary inventions or technology advancements at ground level in health and agriculture sectors. These sectors are not neglected by government; government is trying its level best to increase funding from its budget. The scientific development is always calculated in terms of billions and business terms, it does not indicate the level of benefit people got in these sectors through public funding research institutes.

\subsection{The Government can show its presence in Technology welfare governance}

It is impossible to categorize an Invention good or bad depending on the technical structure or subject category. It always depends on the technical capabilities of destruction or benefit. In this way, the motive of that technology creation and motives of a good government on it is usage, both are important to consider and characterize a technology. In a knowledge economy where technology innovation is the primary goal, the motives of a technology may be questioned by the people because of failures in implementation or lack of technology absorption capacity of the people. Sometimes this may create a strange situation where a beneficial technology may be considered as bad by the public and government is in dock. In democratically elected governments this happens quite often than authoritarian governments. To tackle such type of situations in the highly innovative knowledge economy the governments should practice a paradigm shift towards "Technology welfare governance policy". This will be helpful in tackling problems of many techno innovations related to health and agriculture biotechnology.

The Government can provide an institutional mechanism for implementation and presence of government in this process will increase the accountability and responsibility of public research institutes towards its funding and diffusion of innovations. The zeal of the policy agencies on result oriented projects will increase till the technology diffusion of the project, the government presence will boost their confidence. Technology welfare governance policy deals many aspects like technology governance, implementation, technology absorption, technology benefit parameters and innovation preparedness. Innovation preparedness improves capacity levels of the people to absorb the innovations.

The linkages between research institutes at higher level should be connected with proper mechanism (Fig: 2\&3). The creation of new institutions for extension programmes, technology diffusion, and innovation identification institutions are good to maintain system at top level moreover multiplication of institutions, multiplication of reports will add to more confusion and rigidity in the system at implementation.

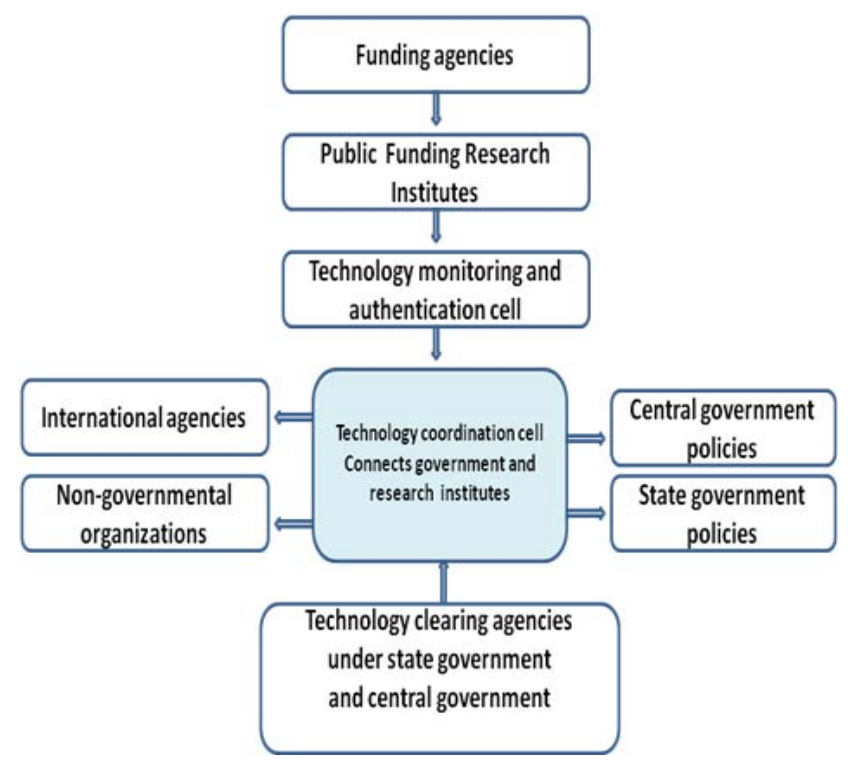

Figure 2: The Technology monitoring and authentication cell to be created and monitored by higher level authority at public research institutes and transferred to "Technology coordination cell" in the government. This cell coordinates innovations to implementation in coordination with government policies and need assessment.

\subsection{Introspection on public funding research institutes in welfare governance}

\subsubsection{The dual role of an Innovator: As Business} Manager and as implementer

This part of the paper highlights the role of a researcher and public research institute as an important part of the Techno welfare governance.

The researchers of the public funding agencies are basically innovators with service mind. From the past decades the funding in public research institutions and researches particularly in developing countries are nurtured to work for public benefit but now this strength became weakness and unable to compete with world needs. Now time has come to change the way of thinking and working. They perform research and publish in the research journals, this is the proof of their service but this is one point where we may have to keep attention to deliver needful technologies.

In India the thinking of public benefit has increased with the success of green revolution. The increase in public funding in agriculture research increased ten folds to give more improved technologies to farmers (seed verities, less dependency on fertilizers) at the same time the investments in private companies also increased hundred fold to do business in this sector. Here there are clear limitations to Public research and private funding research. These companies are not waiting for the technologies from the government institutions to be developed and marketed by them. Companies in Pharma and agriculture making large investments in research and development sections look for profits. When we are in market economy competition will exist. Both public research organizations and private companies coexist in the same environment facing the same 


\section{International Journal of Science and Research (IJSR) \\ ISSN (Online): 2319-7064}

Index Copernicus Value (2015): 78.96 | Impact Factor (2015): 6.391

problems and viewing the same goals but the end goal for them is clearly different.

Nowadays, the researchers are more burdened with the extra responsibilities of the government and the private industry to take care of the additional duties like patents, legal and ethical clearances, administrative hassles for resource allocations and at technology side valuation, pricing and licensing of research outputs. The duel roll responsibilities of a Business Manager occupying the space of the research bench, if the government is interested in that technology, the innovator may have to act as an implementer.

\subsubsection{Benefit and Demand: The balancing act of Public research Institutes in welfare and Business.}

Today in the unbalanced situations of the world many of the public research organisations are better performing in research and innovations but facing failures in transferring the technology benefits to the poor. There may be some difficulties with the public research institutions in this regard.

Every project may not be an innovation or every project may not deliver technologies which can be commercialised but governments have to be with some mechanisms which can work simultaneously with research organizations to identify and classify the useful technologies. As of now government organisations may say that they have well established systems for protection of research and technology transfer mechanism but there is only one scale to prove their claims, that is public benefit at ground level. The arm chair scientific reports, studies, analysis may not help in this. In private research organizations there won't be arm chair scientific staff because their goals are clear. They work for the innovations and work till the implementation level. There is an established mechanism to turn research investments into profit. The investments are clear and accountable, the innovations are clear and marketable and they will get clear profits. Public research organizations also must be clear in the goals of innovations and implementation. There is an urgent need of introspection for the public research institutes. The goals achieved on the paper may not serve any purpose to the poor.

The public advantage of these research funding happens when the public research institutes can be able to differentiate public benefit and demand through their technology transfer policy guideline .For the public research institutes public benefit and demand in market for innovations both are important, but the public funding research motive should not be earning cores with commercialisation of technology but giving benefit to the one core people is important.

\subsubsection{Transferring Technology Benefits to the Public- A general rule for Public funding research}

There are many problems for public research institutions in identifying their goals in technology transfer, pricing and valuation mechanisms. The main problem may be failure in foresee the technology needs, lack of view on implementation, utilization of technologies, technology innovations inconsistency with government policies, competition from market in reaching end users. In present system most of the countries, international organizations, philanthropic societies and NGOs involves in many types of research but an established policy is required to implement the innovations through government. This policy should bring innovation strategists and implementers together and lead the process of innovation preparedness for the success of technology. Now public research Institutes working as technology outlets and the technology reaches public through the market.

\subsubsection{Technology Pricing -valuation and maximization of benefits}

1) Technology classification and categorization on the basis of benefit to the end user and demand in the market. 
International Journal of Science and Research (IJSR)

ISSN (Online): 2319-7064

Index Copernicus Value (2015): 78.96 | Impact Factor (2015): 6.391

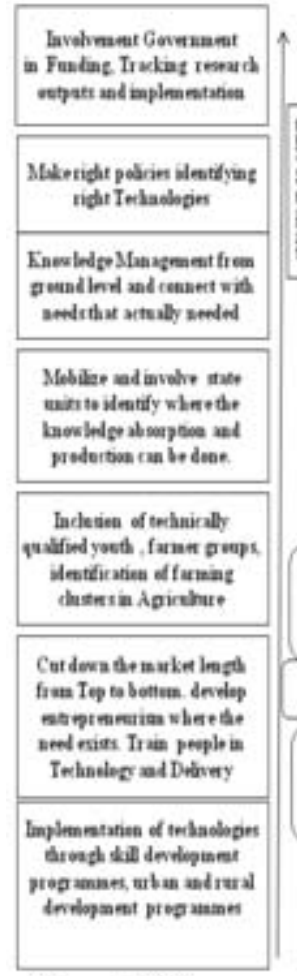

Figure 3: "Govemance of Technology Transfer": for the govemment. This should work in combination with "Public funding Research innovations-Four comered Technology management Model".

2)Identifying market pull technologies and market push technologies.

3) Valuation of technologies using different existing methods.

4)Pricing depends on the consideration value and parameters. Ex: Type of technology, utilization, zone of end-users, demand, market comparative charts, similar technology available, legal status, patent filed or approved. There is no single mechanism. It is Case specific.

5)Estimating value of the available technologies based on Qualitative Methods. These methods are for the purpose of accounting and book keeping. This value is only a consideration but not the final selling price. The historic cost approach to measure the costs incurred through the development of the IP, at the time it was developed. The replication cost approach is to measure the amount of investment needed to develop similar IP, at the present time, in exactly the same way and achieving the same IP as currently exists. The historic cost and replication cost approach values will give the base line amount or real cost on a particular date technology innovated. Replication cost can be taken on the date of submission to the technology transfer department (it is must if the technology is more than 12 months old) to get an idea on the selling price. If the same technologies want to be replicated, the amount of time and cost needed can be taken in to consideration for selling the technology.

3.5.5. "Public funding Research innovations - Four cornered Technology management Model".

The objective of proposed model for the public funding agriculture research institutes is to balance its base line between public benefit and market demand. (Fig: 4).
Policy reflective Technology management

Public Research organizations

Technology Management

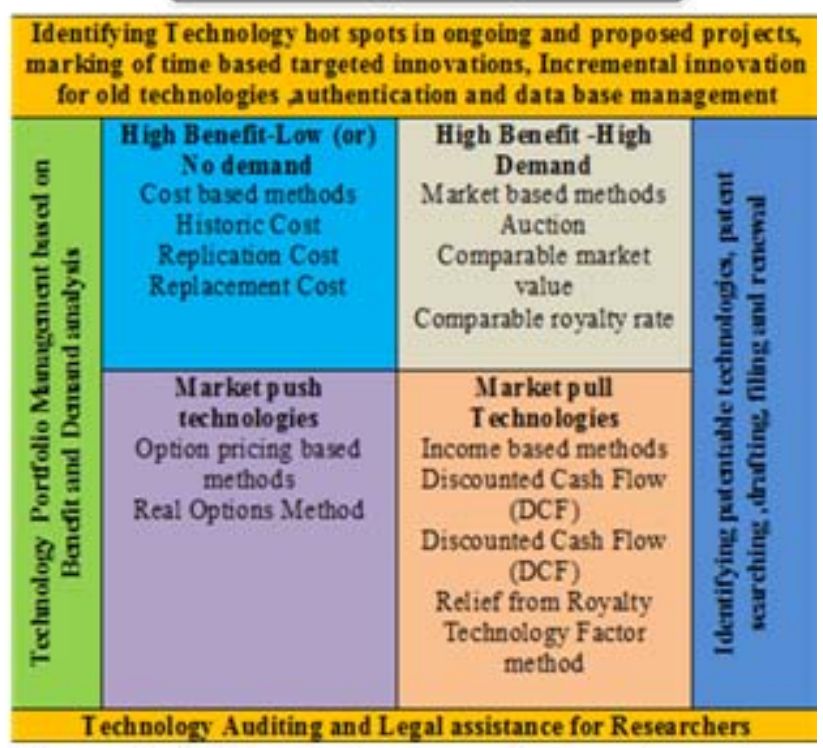

Figure 4: "Public funding Research innovations - Four comered Techno logy manage ment Model" for public research institutes.
This method clears the confusion of public funding research organisations on how to valuate innovations on basis of Public Benefit and Market Demand. Benefit levels to public should be given importance than demand. These valuation methods are case specific. We can apply any single method or combination of methods for technology ${ }^{[5]}$. Four corners of this model can help a research organisation to maintain its technology audit, market value of the outputs, to identify the beneficiaries or end users and market channels to reach people if needed. This can be useful in technology valuation, pricing for technology transfer, licensing activities with industrial collaborations and asserting benefit levels and preparation memorandum of understanding preparations and standard terms of agreement for international collaborations.

Other than this, the model helps funding agencies to identify technology hot spots on the basis of need assessment of endusers in proposed projects, marking of time based targeted innovations, incremental innovation for old technologies, and authentication and data base management at higher levels. The Technology Portfolio Management of research outputs based on Benefit and Demand analysis removes accumulation of detriment technologies with technology management centres.

The model helps innovators in taking decisions on the outputs to serve the purpose of agriculture research. These are innovate and implement it in public domain, aligning them with public policies, maintain research thrust, national, international and institutional collaborations and to balance the monopoly of scientific technologies by private companies. The technologies which need market support 


\section{International Journal of Science and Research (IJSR) \\ ISSN (Online): 2319-7064}

Index Copernicus Value (2015): 78.96 | Impact Factor (2015): 6.391

should be ensured that the technology should not be exploited for market gains.

This model mentions the importance of Technology Auditing and scientific legal support on patent searching, drafting, filing, renewal for scientists in public research institutions. Duplication of research and authenticity and validity of claims about their innovations by scientists can be monitored in national interest. The Technology Auditing cell helps in identify and differentiate basic, applicative, adaptive and patentable technologies in project proposals in terms of budget and outputs.

This model stands to differentiate the definitions of applied research and basic research on the basis of output. The third category belongs to adaptive research which is elongation of the both. Basic research is always long term and a collaborative effort of many institutions all over the world. The applicative research is technology output oriented in a fixed time gives quick technologies. These goals should not be so long till the time public need evaporates. The report based on this model guides the institutions to extent project targets or closure of unnecessary expenditures in network projects. The "Public funding Research innovations - Four cornered Technology management Model" will give way to establish young innovation centres at ground level and utilize their skills in implementations.

3.5.6. Benefit and Welfare: The connectivity between Public funded research and Government

Any research starts with an existing problem or a hypothetical concept. Researchers can give a technology which will benefit large number of people but government should be capable of assimilating it in public welfare policy. Public funding research institutes are domain of innovators, government involves only at the level of funding and not at the level of giving direction to technology dissemination.

A researcher as an innovator cannot think or extent his ability to pilot level of implementation at ground level on his own. Here government should lend its hand through supplementary agencies and take initiatives to implement as a policy.

The scientific development is always calculated in terms of publications, citations, website views and patents. This will show advancement of scientific research but the advancement of science is not equal to the benefit people. It is important the science and technology innovation policy should be integrated into public policy goals, giving particular focus to the nexus between STI, culture, education and development [6]. The public also equal partners in getting benefits of the public research. Research institutes should take optimized decisions in commercialisation, pricing, valuation of the technologies.

The public funding research institutes and mainly agrarian countries should first prefer the ways reach more people with the outputs. The private companies make investments to earn money and public funding research organizations will work on the same problems to win public trust and to give benefit to people.
Government should show it is presence through technology welfare policy implementation. If the market is the only mode for implementation of technology then government and the institutes also should have some monitoring mechanisms on it. Keeping the technology in the free market hands and leaving them on their own never serve the public benefit. Every product that comes in to the market will carry its brand value, production and marketing costs, when the technology is transferred to the private companies the public will go under double taxation by the same government. The responsibility of the government research institutions is much bigger than the private research institutes because they are answerable to the public for their actions and innovations. In this situation intangible assets became more valuable and tangible assets created by scientists became prone to technology theft. So technology protection is also important.

Market and public research both should be seen on different parameters of demand and benefit. The technological innovations are transferred to private companies to implement, but a welfare government has to play its role sharing the research benefits to the people.

In many of the developing countries researches funding in government research institutes are still low in their GDP. Few countries because of their natural, human and technical resources doing research as par with developed countries. Before the research benefits reach the people these benefits are converting in to patents and goes to the market. Rich countries always polarise their policies to influence the markets of developing countries. The countries who are at nascent stages in their patent systems trying to fallow the international norms but in reality the developing countries are at loss because they can't even imitate the technology for the benefit of the people finally the benefits of research are reaching to people in through market mode.

\section{Conclusion}

a) Technology welfare governance policy should be part of Technology Innovation Policy. This will help the government to channelize many inventions which is about to come in future.

b)India requires Technology welfare governance as a continuation of government pro-active programs towards promoting innovations through startups, innovation hubs, incubates centers in research institutes, universities.

c) Introducing Technology welfare governance policy will fasten India efforts to achieve the Millennium Development Goals (MDG by UN) from the goal of knowledge-based economy.

d) Technology Benefit parameters and Innovation capacity parameters are must for public funding research institutes to bring out more efficient innovations balancing basic and applied research. This will show advancement of scientific research.

e) Intellectual studies on Innovation preparedness, technology impact \& absorption should be encouraged by research scholars to tackle ethical, legal, health concerns of the public in using technologies related to Biotechnology. This 


\section{International Journal of Science and Research (IJSR) \\ ISSN (Online): 2319-7064}

Index Copernicus Value (2015): 78.96 | Impact Factor (2015): 6.391

will help in reducing the gap between scientific community and public in future.

f) The project budget and technology output and return on profits, research publications are not real parameters to do public good. Government should create parameters of public benefit for research outputs. The public funding research institutes and mainly agrarian countries should first prefer the ways reach more people with the outputs.

g) Technology diffusion capability of a country depends on the scientific advancement, knowledge levels of the country, human capital, income levels, and technology absorption capacity of the people, need assessment and capability of integrating innovations with policies. For this government has to overcome technical, environmental, economic and administrative challenges at implementation.

h)High Benefit -High Demand: These are the diamond technologies which an institute can benefit to improve its image. These type technologies are very difficult to create and rare. Implementation and Development of this type of technologies will give a chance to the research institutes and government to innovate and renovate them. These technologies test the capability of a welfare government in reaching public

i) This concludes that, agriculture technology outcomes from public funding research institutes should be in more realistic targets and the successful innovations should prefer for present needs and future needs.

j) Best-practices of research institutes, universities and Bestpractices of technology transfer should be implemented to balance public benefit and private partnerships.

\section{References}

[1] Jerome H. Reichman \& Keith H. Maskus, The Globalization of Private Knowledge Goods and the Privatization of Global Public Goods, Journal of International Economic Law 279-320(2005).

[2] Pluvia Zuniga. "The State of Patenting at Research Institutions in Developing Countries: Policy Approaches and Practices". WIPO ECONOMIC RESEARCH WORKINGPAPERS. Working Paper No. 4 December 2011.

[3] Centre for Environment Education (CEE). 2010. " National Consultations on GM brinjal Report”. Retrieved on 15 November 2010.

[4] Henry M Biswas and Alex R Gauchi. "An investigation into factors that influence the diffusion and adaption of inventions and innovations from research institutes and universities in Kenya". ATPS working paper 19, Sept 1999.Published by: The African technology policy studies network. Nairobi, Kenya.

[5] Robert Pitkethly. The Said Business School, University of Oxford, Park End Street, Oxford OX1 1HP \& Oxford Intellectual Property Research Centre St. Peter's College, Oxford OX1 2DL. ".THE VALUATION OF PATENTS: A review of patent valuation methods with consideration of option based methods and the potential for further research". This paper has also been published as: Judge Institute Working Paper WP 21/97 The Judge Institute of Management Studies Trumpington Street, Cambridge CB2 $1 \mathrm{AG}$
[6] "UN System Task Team on the post-2015 UN development agenda: Science, technology and innovation for sustainable development in the global partnership for development beyond 2015 Thematic Think Piece" ITU,OHCHR, UNCTAD, UNEP, UNESCO, UNFCCC, UNIDO, WIPO, WMO.

\section{Author Profile}

Mr. Vithal Kumar Lakkineni: Doctoral student of Center for Research Studies, Noida International University, Noida. UP. He holds a Master degree in Biotechnology. Apart from that he had done MBA International Business management, One Year Course in Science Journalism (NCSTC-DST-GOI), Post Graduate Diploma in IPR (IGNOU) and from WIPO, Geneva DL-450-Intellectual Property Management, DL-318 Patent Information Search, DL-204 Biotechnology and Intellectual Property, DL-320 Basics of Patent Drafting.

Dr. Archana Tiwari: Director, School of life sciences Noida International University. Besides her basic research areas of Algal biofuels, Cyanotoxins and Allelopathic impact of Microalgae, she had promoted diverse academic initiatives towards improving student's awareness on the importance of technology innovation capacity in the university. With Fifteen years of academic excellence and strong scientific zeal to contribute to the society, she is playing a fundamental role in inspiring doctoral students to take up studies on Knowledge management, scientific policy and Intellectual property rights for academic research. 